\title{
Kombinasi Regresi Tak Bias Ridge dengan Regresi Komponen Utama untuk Mengatasi Masalah Multikolinieritas
}

\author{
FITRIANA NOVITASARI, SULIADI, ANNEKE ISWANI A. \\ Prodi Statistika, Fakultas Matematika dan Ilmu pengetahan alam, Universits islam Bandung, \\ Jl.Tamansari No. 1 Bandung 40116 \\ e-mail: fitriananovitasari@gmail.com
}

\begin{abstract}
ABSTRAK
Metode kuadrat terkecil (MKT) merupakan salah satu metode penaksir parameter regresi. Dalam metode MKT terdapat salah satu asumsi yang harus dipenuhi yaitu tidak adanya multikolinieritas. Multikolinieritas merupakan hubungan linier antara sesama variabel bebas $(X)$ yang akan berakibat pada ragam penduga koefisisen regresi menjadi besar sehingga menyebabkan selang kepercayaan untuk parameter regresi cenderung akan lebih lebar. Salah satu metode yang dapat digunakan untuk mengatasi multikolinieritas adalah regresi MCRR, dimana metode MCRR ini merupakan kombinasi antara regresi tak bias ridge (URR) dan regresi komponen utama. Makalah ini akan membahas penanganan multikolinieritas dengan menggunakan MCRR, sebagai bahan aplikasi akan digunakan data tingkat produksi Crude Palm Oil (CPO) .
\end{abstract}

Kata Kunci: Metode kuadrat terkecil, Unbiased Ridge Regression , Regresi Komponen Utama, Penaksir kelas ( $\mathrm{r}, \mathrm{k})$, Modified (r,k) Class Ridge Regression (MCRR), Multikolinieritas.

\section{PENDAHULUAN}

Analisis regresi merupakan suatu teknik analisis statistik untuk membuat model dan mengetahui hubungan antara dua variabel atau lebih. Salah satu dari model statistika yang sering digunakan dalam pemecahan suatu masalah adalah model regresi linier. Hubungan dalam model tersebut dapat dinyatakan dalam bentuk persamaan yang menghubungkan variabel tak bebas $(Y)$ dengan satu atau lebih variabel bebas $(X)$.

Salah satu cara untuk mendapatkan koefisien regresi linier berganda adalah menggunakan metode kudrat terkecil (MKT). Dalam MKT terdapat salah satu asumsi yang harus di penuhi yaitu tidak adanya multikolnieritas atau tidak ada hubungan antar variabel bebas $(X)$. Jika antara variabel bebas $(X)$ terdapat hubungan (mulikolinieritas) maka akan menyebabkan ragam penduga koefisien regresi menjadi besar sehingga selang kepercayaan untuk parameter regresi juga cenderung akan lebih lebar. Untuk mendeteksi apakah terdapat multikolinieritas atau tidak, dapat dilihat dengan Variance Inflation Factors (VIF). Jika nilai dari VIF > 10 maka dapat dinyatakan bahwa dalam variabel bebas tersebut terdapat multikolinieritas (Myers, 1990).

Untuk mengatasi masalah mutikolinieritas dapat dilakukan dengan menggunakan regresi ridge. Metode ini pertama kali dikemukakan oleh Hoerl dan Kennard (1970). Namun regresi ridge memiliki kekurangan yaitu sifat penaksir regresi ridge adalah bias. Oleh karena itu Crouse, et al., (1995) meningkatkan kinerja regresi ridge yang diberi nama Unbiased ridge regression (URR), dimana penaksir yang dihasilkan URR merupakan penaksir yang tidak bias bagi $\beta$. Selain itu Marquardt, 1970 mengusulkan regresi komponen utama sebagai alat untuk menangani multikolinieritas, dan Baye dan Parker (1984) memodifikasi regresi komponen utama dengan menggabungkan regresi komponen utama dengan regresi ridge yang dinamakan penaksir $(r, k)$ dimana $r$ merupakan banyaknya komponen yang terpilih sedangkan $k$ merupakan sebuah konstanta positif dari regresi ridge, untuk meminimumkan nilai standar error dari regresi komponen utama, Batah, et al. (2009) meningkatkan metode penaksir $(r, k)$ yang di usulkan oleh Baye dan Parker (1984) yaitu dengan menggabungkan penaksir $(r, k)$ 


\section{Fitriana Novitasari dkk.}

dengan penaksir tak bias regresi ridge (unbiased ridge regression / URR) dimana penaksir baru ini dinamakan modified $(r, k)$ class ridge regression (MCRR).

Dalam penelitian ini akan membahas metode MCRR untuk menangani masalah multikolinieritas, yang akan diterapkan pada data tingkat produksi Crude Palm Oil (CPO) yang dipengaruhi oleh jumlah buah kelapa sawit, jumlah tenaga kerja, jam kerja mesin, penggunaaan air, penggunaan uap dan suplay listrik di Unit Adolina PT. Perkebunan Nusantara IV Sumatra Utara.

\section{TINJAUAN PUSTAKA}

\section{Regresi Linier Berganda}

Analisis regresi merupakan suatu metode statistik yang digunakan untuk memodelkan hubungan antara variabel tak bebas $(Y)$ dengan variabel bebas $(X)$. Misalkan $Y_{i}$ adalah respon pengamatan ke-i, dan $X_{i}=\left(1, X_{i 1}, X_{i 2}, \ldots, X_{i p}\right)^{T}$ adalah vektor variabel bebas pengamatan ke-i, maka hubungna antara variabel tak bebas $(Y)$ dengan variabel bebas $(X)$ dapat dinyatakan sebagai berikut :

$Y_{i}=\beta_{0}+\beta_{1} X_{i 1}+\beta_{2} X_{i 2}+\cdots+\beta_{P} X_{i p}+\varepsilon_{i}$

Dalam bentuk matrik dapat dinyatakana sebegai berikut:

$Y=X \beta+\varepsilon$

Dimana $Y=\left(Y_{1}, Y_{2}, \ldots, Y_{p}\right)^{T}$ dan $\beta=\left(\beta_{1}, \beta_{2}, \ldots, \beta_{p}\right)^{T}$ merupakan parameter koefisien regresi.

Untuk menaksir parameter-parameter dari persamaan (2.1) dapat digunakan metode kuadrat terkecil (MKT). MKT merupakan metode penaksir yang bertujuan untuk meminimumkan jumlah kuadrat kesalahan $\sum e_{i}{ }^{2}$ sehingga nilai penaksir regresinya akan mendekati nilai yang sesungguhnya. Penaksir MKT bagi $\beta$ adalah:

$\widehat{\boldsymbol{\beta}}=\left(\boldsymbol{X}^{t} \boldsymbol{X}\right)^{-1}\left(\boldsymbol{X}^{t} \boldsymbol{Y}\right)$

Dalam MKT terdapat salah satu asumsi yang harus dipenuhi yaitu tidak ada hubungan linier (multikolinieritas) diantara variabel-variabel bebas. Untuk melihat apakah suatu model mengalami multikolinierits, dapat dilihat menggunakan nilai Variance Inflation Factors (VIF). Nilai VIF dapat diperoleh dengan persamaan :

$V I F_{j}=\frac{1}{1-R_{j}{ }^{2}}$

dimana $R_{j}^{2}$ merupakan koefisien determinasi dari regresi antara variabel bebas $\left(X_{j}\right)$ yang diregresikan terhadap variabel bebas lainya. Apabila Nilai VIF lebih besar dari 10 dapat dijadikan indikasi bahwa ada masalah multikolinieritas atau dapat diindikasi bahwa ada hubungan diantara variabel bebas (Myers, 1990).

Jika asumsi tidak adanya multikolinieritas ini dilanggar, terdapat beberapa alternatif untuk menangani masalah ini diantaranya adalah metode penaksir regresi ridge dan penaksir komponen utama, kedua penaksir ini akan di jelaskan pada sub bagian berikut ini.

\section{Penaksir Regresi Ridge}

Regresi ridge pertama kali diperkenalkan oleh Hoerl dan Kennard (1970) . Metode ini dilakukan dengan cara menambahkan konstanta yang bernilai positif $\lambda$ terhadap elemen diagonal $X^{* t} X^{*}$. Dimana $X^{*}$ merupakan nilai dari variabel bebas $X$ yang telah di standarkan.

Penaksir parameter regresi ridge dilakukan dengan cara menstandarkan variabel bebas dan variabel tak bebas dengan model (Kutner, et al., 2005):

$y_{i}{ }^{*}=\beta_{1}{ }^{*} X_{i 1}{ }^{*}+\beta_{2}{ }^{*} X_{i 2}{ }^{*}+\cdots+\beta_{p}{ }^{*} X_{i p}{ }^{*}+\varepsilon_{i}$

Dimana $X_{i}^{*}$ dan $Y_{i}^{*}$ adalah $X_{i}$ dan $Y_{i}$ yang telah di standarkan.

Penaksir regresi ridge bagi $\beta_{R}=\left(\beta_{1}{ }^{*}, \beta_{2}{ }^{*}, \ldots, \beta_{p}{ }^{*}\right)^{T}$ adalah:

$\widehat{\boldsymbol{\beta}}_{R}(\lambda)=\left(\boldsymbol{X}^{* t} \boldsymbol{X}^{*}+\lambda \boldsymbol{I}\right)^{-1} \boldsymbol{X}^{* t} \boldsymbol{Y}^{*}$

dimana $I$ adalah matrik identitas berukuran $(p \times p)$, dan $\lambda$ adalah suatu konstanta positif dengan $\lambda>0$. 
Dalam prakteknya nilai optimal $\lambda$ pada persamaan (2.4) tidak diketahui. Salah satu penaksir $\lambda$ yang diusulkan oleh Hoerl dan Kennard (1970) adalah sebagai berikut:

$\hat{\lambda}=\frac{p S_{M K T}{ }^{2}}{\widehat{\boldsymbol{\beta}}_{M K T} \widehat{\boldsymbol{\beta}}_{M K T}}$

dimana nilai $\widehat{\boldsymbol{\beta}}_{M K T}$ dapat diperoleh dari persamaan (2.2), dan $S^{2}$ adalah ragam model (2.1).

$S_{M K T}^{2}=\frac{\left(\boldsymbol{Y}-\boldsymbol{X} \widehat{\boldsymbol{\beta}}_{M K T}\right)^{T}\left(\boldsymbol{Y}-\boldsymbol{X} \widehat{\boldsymbol{\beta}}_{M K T}\right)}{n-p}$

untuk mengembalikan model regresi ridge ke model asalnya dapat di lakukan dengan persamaan berikut:

$\hat{\beta}_{0}=\bar{Y}-\left(\hat{\beta}_{1} \bar{X}_{1}+\hat{\beta}_{2} \bar{X}_{2}+. .+\hat{\beta}_{P} \bar{X}_{P}\right)$

$\hat{\beta}_{j}=\left(\frac{s_{y}}{s_{j}}\right) \beta_{P}{ }^{*} ; j=1,2, \ldots, P$

\section{Unbiased Ridge Regression (URR)}

Penaksir yang dihasilkan oleh regresi ridge adalah bias, oleh karena itu Crouse et al., (1995) memperkenalkan suatu metode untuk memperbaiki kinerja regresi ridge yaitu unbiased ridge regression (URR). Penaksir URR ini mampu menghasilkan penaksir yang tak bias untuk $\beta$. Penaksir URR dilakukan dengan cara mengkombinasikan nilai informasi sebelumnya $(J)$ dengan $\lambda$.

Penaksir yang tak bias untuk $\beta$ menggunakan penaksir URR adalah sebagai berikut:

$\widehat{\boldsymbol{\beta}}_{U R R}(\lambda, J)=\left(\boldsymbol{X}^{* t} \boldsymbol{X}^{*}+\lambda^{*} \boldsymbol{I}\right)^{-1}\left(\boldsymbol{X}^{* t} \boldsymbol{Y}^{*}+\lambda^{*} \boldsymbol{J}\right) ; \quad$ untuk $\lambda \geq 0$

Dimana $J$ adalah suatu vektor acak yang berdistribusi normal $J \sim N\left(\beta, \frac{\sigma^{2}}{\lambda} I\right)$ untuk $\lambda>0$. Crouse, et al., (1995) memberikan salah satu nilai $J$ yang dapat digunakan yaitu:

$\boldsymbol{J}=\eta \mathbf{1}_{p \times 1}$

dengan:

$\eta=\frac{1}{p} \sum_{j=1}^{p} \hat{\beta}_{j}$

Nilai $\lambda^{*}$ pada persamaan (2.5) dapat diperoleh melalui persamaan sebagai berikut (Crouse, et al., 1995):

$\hat{\lambda}^{*}=\frac{p \sigma^{2}}{\left(\widehat{\boldsymbol{\beta}}_{M K T}-J\right)^{t}\left(\widehat{\boldsymbol{\beta}}_{M K T}-J\right)-\sigma^{2} \operatorname{tr}\left(\boldsymbol{X}^{* t} \boldsymbol{X}^{*}\right)^{-1}}$

Jika $\left(\widehat{\boldsymbol{\beta}}_{M K T}-\boldsymbol{J}\right)^{t}\left(\widehat{\boldsymbol{\beta}}_{M K T}-\boldsymbol{J}\right)-\sigma^{2} \operatorname{tr}\left(\boldsymbol{X}^{* t} \boldsymbol{X}^{*}\right)^{-1}>0$

dan

$\hat{\lambda}^{*}=\frac{p \sigma^{2}}{\left(\widehat{\boldsymbol{\beta}}_{M K T}-\boldsymbol{J}\right)^{t}\left(\widehat{\boldsymbol{\beta}}_{M K T}-J\right)} \quad$, untuk yang lain

Jika nilai $\sigma^{2}$ tidak diketahui, maka $\sigma^{2}$ dapat di ganti dengan penaksir yang tak bias dari $\hat{\sigma}^{2}$ yaitu

$S^{2}=\frac{\left(\boldsymbol{Y}-\boldsymbol{X} \widehat{\boldsymbol{\beta}}_{M K T}\right)^{t}\left(\boldsymbol{Y}-\boldsymbol{X} \widehat{\boldsymbol{\beta}}_{M K T}\right)}{(n-p-1)}$

\section{Penaksir Regresi Komponen Utama (PCR)}

Regresi komponen utama didasarkan pada analisis komponen utama. Melalui analisis komponen utama akan dihasilkan variabel-variabel baru (komponen utama) yang merupakan kombinasi linier dari variabel-variabel bebas asal, dan antara variabel baru ini bersifat tidak saling berkorelasi. Selanjutnya variabel bebas (komponen utama) akan diregresikan dengan variable terikat $(Y)$. Langkah awal sebelum melakukan regresi komponen utama adalah menstandarkan variabel bebas $(X)$, untuk matrik variabel bebas $(X)$ yang telah di standarkan di lambanghan $X^{*}$.

Dari variabel bebas yang telah di bakukan akan di peroleh akar ciri $(\delta)$ dan vektor ciri $(v)$ dari $X^{* t} X^{*}$. Untuk menentukan akar ciri (eigen value) $\delta_{1}, \delta_{2}, \ldots, \delta_{p}$ dapat di peroleh dari penyelesaian sistem persamaan linier berikut $\left|\boldsymbol{X}^{* t} \boldsymbol{X}^{*}-\delta \mathrm{I}\right|=0$. Vektor ciri $v_{i}$ untuk akar ciri $\delta_{i}$ diperoleh dari penyelesaian $\left(\boldsymbol{X}^{* t} \boldsymbol{X}^{*}-\delta \boldsymbol{I}\right) v=0 . \delta_{1}, \delta_{1}, \ldots, \delta_{p}$ merupakan ragama dari komponen utama ke $1,2, \ldots, p$. 


\section{Fitriana Novitasari dkk.}

Untuk penentuan banyaknya komponen yang akan digunakan yaitu dengan melihat proporsi komulatif keragaman data minimal 80\% (Johnson, 2007), atau dengan menggunakan scree plot (Rancer, 1998).

Nilai komponen utama $Z_{j}$ untuk masing-masing observasi adalah :

$\boldsymbol{Z}=\boldsymbol{X}^{*} \boldsymbol{V}$

dimana $Z$ adalah matrik $(n \times p)$. Kolom dari matrik $Z$ didefinisikan sebagai variabel bebas baru (komponen utama) yang saling orthogonal yaitu $Z=\left[Z_{1}, Z_{2}, \ldots, Z_{p}\right]$. Sedangkan $\boldsymbol{V}$ merupakan matrik $(p \times p)$ dimana kolom-kolomnya merupakan vektor ciri dari $X^{* t} X^{*}$. Matrik $\boldsymbol{V}$ merupakan sebuah matrik orthogonal yang memenuhi persamaan $\boldsymbol{V}^{\boldsymbol{t}} \boldsymbol{V}=\boldsymbol{I}$.

Oleh karena itu, $\boldsymbol{X} \boldsymbol{\beta}$ pada persamaan (2.2) dapat dinyatakan sebagai :

$\boldsymbol{X} \boldsymbol{\beta}=\boldsymbol{X} \boldsymbol{V} \boldsymbol{V}^{t} \boldsymbol{\beta}$

$=Z \alpha$

Maka persamaan regresi linier berganda dapat dinyatakan sebagai model regresi komponen utama seperti berikut ini (Jollife, 2002):

$\boldsymbol{y}=\boldsymbol{Z} \boldsymbol{\alpha}+\boldsymbol{\varepsilon}$

dimana $\boldsymbol{\alpha}$ adalah vektor berukuran $(p \times 1)$ dengan bentuk $\boldsymbol{\alpha}=\boldsymbol{V} \boldsymbol{\beta}$

Model umum dari regresi komponen utama adalah seperti yang di tunjukan dalam persamaan (2.6), model tersebut digunakan jika semua $p$ variabel bebas dimasukan dalam komponen, namun jika hanya $r$ komponen yang diambil maka model regresi komponen utama adalah :

$\boldsymbol{y}=\boldsymbol{Z}_{\boldsymbol{r}} \boldsymbol{\alpha}_{\boldsymbol{r}}+\boldsymbol{\varepsilon}_{\boldsymbol{r}}$

dimana $\alpha_{r}$ merupakan sebuah vektor dari unsur komponen yang terpilih sebanyak $r$ yaitu bagain dari unsur $V . \quad Z_{r}$ adalah matrik berukuran $(n \times r)$ yang kolom-kolomnya merupakan bagian dari $Z$. Dengan menggunakan penaksir kuadrat terkecil untuk mengestimasi $\alpha$ di persaman (2.7) maka:

$\widehat{\boldsymbol{\alpha}}_{r}=\left(\boldsymbol{Z}^{t}{ }_{r} \boldsymbol{Z}_{r}\right)^{-1} \boldsymbol{Z}_{r}^{t} \boldsymbol{y}$

$$
=\Lambda^{-1} \boldsymbol{Z}^{t} \boldsymbol{y}
$$

dengan : $\alpha_{r}=\left[\alpha_{1}, \alpha_{2}, \ldots, \alpha_{r}\right]^{t}, Z_{r}=\left[Z_{1}, Z_{2}, \ldots, Z_{r}\right]$ dan $\Lambda$ merupakan matrik diagonal yang diagonal utamanya adalah nilai $r$ akar ciri terbesar dari matrik $X^{* t} X^{*}$. Sedangkan matrik varian kovarian dari $\hat{\alpha}$

$\operatorname{var}\left(\hat{\alpha}_{r}\right)=\sigma^{2} \Lambda^{-1}$

Jadi penaksir komponen utama $\hat{\beta}_{P C R}$ utama dapat ditulis :

$$
\begin{aligned}
& \hat{\beta}_{P C R}=\boldsymbol{V}_{r}\left(\boldsymbol{V}_{r}{ }^{t} \boldsymbol{X}^{t} \boldsymbol{X} \boldsymbol{V}_{r}\right)^{-1} \boldsymbol{V}_{r}{ }^{t} \boldsymbol{X}^{t} \boldsymbol{Y} \\
& =\boldsymbol{V}_{r} \Lambda_{r}{ }^{-1} \boldsymbol{V}_{r}{ }^{t} \boldsymbol{X}^{t} \boldsymbol{Y}
\end{aligned}
$$

Untuk meningkatkan kinerja regresi komponen utama Baye \& parker 1984 melakukan peningkatan kinerja regresi komponen utama dengan menggabungkan penaksir tak bias regresi ridge dengan regresi komponen utama. Penaksir baru ini disebut dengan penaksir kelas $(r, k)$ dengan penaksir sebagai berikut:

$$
\begin{aligned}
\widehat{\boldsymbol{\beta}}_{r, k} & =\boldsymbol{V}_{r}\left(\boldsymbol{V}_{r}{ }^{t} \boldsymbol{X}^{t} \boldsymbol{X} \boldsymbol{V}_{r}+\lambda \boldsymbol{I}_{r}\right)^{-1} \boldsymbol{V}_{r}^{t} \boldsymbol{X}^{t} \boldsymbol{Y} \\
& =\boldsymbol{V}_{r}\left(\Lambda_{r}+\lambda \boldsymbol{I}_{r}\right)^{-1} \boldsymbol{V}_{r}{ }^{t} \boldsymbol{X}^{t} \boldsymbol{Y} \text {, untuk } \lambda>0
\end{aligned}
$$

\section{Modified ( $\boldsymbol{r}, \boldsymbol{k})$ Class Ridge Regression (MCRR)}

Penaksir MCRR diusulkan oleh Batah, et al., 2009 merupakan sebuah penaksir dengan menggabungkan penaksir $(r, k)$ dengan unbiased ridge regression (URR). Penaksir untuk $\hat{\beta}_{M C R R}$ adalah sebagai berikut:

$\widehat{\boldsymbol{\beta}}_{M C R R}\left(\lambda^{*}, J\right)=\boldsymbol{V}_{r}\left(\boldsymbol{V}_{r}{ }^{t} \boldsymbol{X}^{t} \boldsymbol{X} \boldsymbol{V}_{r}+\lambda^{*} \boldsymbol{I}_{r}\right)^{-1} \boldsymbol{V}_{r}{ }^{t}\left(\boldsymbol{X}^{t} \boldsymbol{Y}+\lambda^{*} \boldsymbol{J}\right)$

Dari persamaan (2.8) diperoleh (Batah, 2009):

$\operatorname{Bias}\left(\widehat{\boldsymbol{\beta}}_{M C R R}\left(\lambda^{*}, J\right)\right)=\left[\boldsymbol{V}_{r} \boldsymbol{V}_{r}{ }^{t}-\boldsymbol{I}_{p}\right] \boldsymbol{B}$

$=-\boldsymbol{V}_{p-r} \boldsymbol{V}_{p-r}{ }^{t} \boldsymbol{B}$ 
dan

$\operatorname{var}\left(\hat{\beta}_{M C R R}\left(\lambda^{*}, J\right)\right)=\sigma^{2} \boldsymbol{V}_{r}\left(\boldsymbol{V}_{r}^{t} \boldsymbol{X}^{t} \boldsymbol{X} \boldsymbol{V}_{r}+\lambda^{*} \boldsymbol{I}_{r}\right)^{-1} \boldsymbol{V}_{r}{ }^{t}$ $=\sigma^{2} \boldsymbol{V}_{r} \boldsymbol{\Lambda}_{\mathrm{r}}^{-1}\left(\lambda^{*}\right) \boldsymbol{V}_{r}^{t}$

$\operatorname{dimana} \Lambda_{\mathrm{r}}\left(\lambda^{*}\right)=\Lambda_{\mathrm{r}}+\lambda^{*} I_{r}$ dan $\Lambda_{\mathrm{r}}=\boldsymbol{V}_{r}{ }^{t} \boldsymbol{X}^{t} \boldsymbol{X} \boldsymbol{V}_{r}$

Dalam hal ini penaksir MCRR memiliki beberapa sifat yaitu :

1) $\hat{\beta}_{p}(0, J)=\hat{\beta}_{M K T}=\left(X^{t} X\right)^{-1}\left(X^{t} Y\right)$

2) $\hat{\beta}_{p}\left(\lambda^{*}, J\right)=\hat{\beta}\left(\lambda^{*}, J\right)=\left(X^{* t} X^{*}+\lambda I\right)^{-1}\left(X^{* t} Y^{*}+\lambda J\right)$

3) $\hat{\beta}_{r}(0, J)=\hat{\beta}_{P C R}=T_{r}\left(T_{r}{ }^{t} X^{* t} X T_{r}\right)^{-1} T_{r}^{t} X^{* t} Y$

4) $\lim _{\lambda^{*} \rightarrow 0} \hat{\beta}_{M C R R}\left(\lambda^{*}, J\right)=\hat{\beta}_{P C R}$

5) $\lim _{\lambda^{*} \rightarrow \infty} \hat{\beta}_{M C R R}\left(\lambda^{*}, J\right)=J$

Dimana $\hat{\beta}_{p}$ merupakan penaksir $\hat{\beta}_{M C R R}$ jika semua komponen dipakai dalam model.

\section{BAHAN DAN METODE}

Analisis yang akan digunakan untuk menangani multikolinieritas digunakan regresi MCRR, yang akan diaplikasikan pada data sekunder tingkat produksi Crude Palm Oil (CPO) yang dipengaruhi oleh jumlah buah kelapa sawit, jumlah tenaga kerja, jam kerja mesin, penggunaaan air, penggunaan uap dan suplay listrik Unit Adolina PT. Perkebunan Nusantara IV Sumatra Utara (Purba, 2013).

Langkah untuk menganaslisi data yang harus dilakukan adalah :

1) Mencari model MKT $\rightarrow$ menguji asumsi multikolinieritas $\rightarrow$ jika nilai VIF $>10$ maka transformasi data.

2) Menetukan banyaknya komponen yang terpilih

3) Mengitung nilai $\eta$, nilai $J$ dan $\lambda^{*}$

4) Subtitusikan nilai $J$ dan $\lambda^{*}$ kedalam persamaan (2.8) untuk menaksir regresi MCRR.

\section{ANALISIS DAN PEMBAHASAN}

\section{Pemodelan Regresi Metode Kuadrat Terkecil}

Hasil penaksiran parameter berdasakan metode kuadrat terkecil untuk regresi linier berganda didapatkan diperoleh model sebagai berikut :

$\hat{Y}=57.7267+0.2350 X_{1}-0.0508 X_{2}+0.0239 X_{3}-0.0066 X_{4}+0.0096 X_{5}+0.00014 X_{6}$

Melalui persamaan model regresi dengan metode kuadrat terkecil diperoleh nilai $R^{2}$ sebesar 99.5\%, namun meskipun nilai $R^{2}$ cukup tinggi setelah di uji secara parsial, banyak variabel bebas yang tidak signifikan dalam mempengaruhi variabel tak bebas, selain itu dilihat dilihat dari tanda nilai koefisien yang dihasilkan tidaklah masuk akal, jika dilihat variabel $X_{2}$ (jumlah tenaga kerja) memiliki tanda negatif hal ini bebrarti dengan bertambahnya jumlah tenaga kerja maka akan mengurangi tingkat produksi, kesimpulan yang dihailkan dalam model ini tidaklah masuk akal, sehingga hal ini mengindikasikan bahwa adanya masalah multikolinieritas. Untuk hasil uji parsial ditampilkan dalam Tabel 4.1 berikut:

Tabel 4.1 Hasil signifikansi Uji t

\begin{tabular}{|c|c|c|c|c|}
\hline Variabel & Koefisien & t hitung & P-value & Keterangan \\
\hline$X_{1}$ & 0.2350 & 8.97 & 0.000 & Signifikan \\
\hline$X_{2}$ & -0.0508 & -0.52 & 0.603 & Tidak signifikan \\
\hline$X_{3}$ & 0.0239 & 0.11 & 0.914 & Tidak signifikan \\
\hline$X_{4}$ & -0.0066 & -0.36 & 0.719 & Tidak signifikan \\
\hline$X_{5}$ & 0.0096 & 1.82 & 0.077 & Tidak signifikan \\
\hline$X_{6}$ & 0.0001 & 0.63 & 0.529 & Tidak signifikan \\
\hline
\end{tabular}


Untuk memastikan apakah terdapat masalah multikolinieritas dalam data tingkat produksi crude palm oil (CPO), maka dapat menggunakan nilai variance inflation factors (VIF), nilai VIF disajikan pada Tabel 4.2 berikut :

Tabel 4.2 Nilai variance inflation factors untuk setiap variabel bebas $X$

\begin{tabular}{|c|c|}
\hline Variabel & VIF \\
\hline$X_{1}$ & 112.437 \\
\hline$X_{2}$ & 11.303 \\
\hline$X_{3}$ & 12.096 \\
\hline$X_{4}$ & 93.446 \\
\hline$X_{5}$ & 2.420 \\
\hline$X_{6}$ & 2.676 \\
\hline
\end{tabular}

Dari tabel di atas dapat dilihat bahwa variabel $X_{1}, X_{2}, X_{3}$ dan $X_{4}$ memiliki nilai VIF lebih besar dari 10, dengan nilai VIF masing-masing adalah 112.437, 11.303, 12.096, dan 93.446. Oleh karena itu dapat disimpulkan bahwa diantara variabel bebas terdapat masalah multikolinieritas, sehingga dapat disimpulkan bahwa dalam data tingkat produksi crude palm oil (CPO) terdapat kasus multikolinieritas dalam variabel bebasnya.

\section{Penanganan multikolinieritas}

Modified $(\mathrm{r}, \mathrm{k})$ class ridge regression (MCRR)

Dalam Tabel 4.2 terlihat bahwa variabel $X_{1}, X_{2}, X_{3}$ dan $X_{4}$ terindikasi multikolinieritas, oleh karena itu akan dilakukan penanganan masalah multikolinieritas dengan menggunakan metode MCRR. Sebelum menaksir menggunakan regresi MCRR, langkah pertama adalah menentukan banyaknya komponen yang akan diambil dari analisis komponen utama. Untuk menentukan banyaknya komponen yang diambil terdapat beberapa langkah diantaranya:

1) Menstandarkan varaibel bebas $(X)$ untuk hasil dari standarisasi variabel bebas $(X)$ diberikan dalam lampiran.

2) Menentukan nilai akar ciri dan vektor ciri. Dimana untuk nilai akar ciri disajikan dalamTabel 4.3

Tabel 4.3 Akar ciri berdasarkan analisis komponen utama

\begin{tabular}{|c|c|c|c|}
\hline Komponen & Akar cirri & $\begin{array}{c}\text { Keragaman } \\
(\%)\end{array}$ & $\begin{array}{c}\text { Keragaman } \\
\text { komulatif (\%) }\end{array}$ \\
\hline PC1 & 5.1246 & $85.4 \%$ & $85.4 \%$ \\
\hline PC2 & 0.4560 & $7.60 \%$ & $93.0 \%$ \\
\hline PC3 & 0.2791 & $4.70 \%$ & $97.7 \%$ \\
\hline PC4 & 0.0774 & $1.30 \%$ & $99.0 \%$ \\
\hline PC5 & 0.0578 & $1.00 \%$ & $99.9 \%$ \\
\hline PC6 & 0.0050 & $0.10 \%$ & $100 \%$ \\
\hline
\end{tabular}

Dari Tabel 4.3 dapat di lihat banyaknya komponen yang akan digunakan adalah komponen dengan prosentase komulatif dari akar ciri minimal $80 \%$. Dalam kasus ini peneliti akan mengambil dua komponen utama yaitu komponen PC1 dan komponen PC2, karena komulatif keragaman dari kedua komponen ini sebesar $93 \%>80 \%$.

Dalam penaksiran model regresi MCRR penetapan nilai $J$ dan $\hat{\lambda}^{*}$ merupakan hal yang penting, dalam penelitian ini, dengan nilai $\eta$ yang diperoleh sebesar 0.1678 , untuk nilai $J$ nilai $\eta$ dikalikan dengan matrik $1_{p x 1}$, sedangkan nilai $\hat{\lambda}^{*}$ yang dieroleh adalah 0.0373 . Sehingga diperoleh penaksir regresi MCRR dari data yang telah dikembalikan kedalam bentuk awal adalah sebagai berikut:

$\hat{Y}=-315.776+0.04341 X_{1}+0.49865 X_{2}+1.09091 X_{3}+0.03315 X_{4}+0.05342 X_{5}+0.00181 X_{6}$ 
Dari model MCRR diatas diperoleh nilai mean square error (MSE) yang dihasilkan sebesar 137423.59 dengan nilai $R^{2}$ sebesar $96.3 \%$. Jika dilihat dari nilai koefisien dari regresi MCRR ini semua koefisien positif artinya semua variabel berpengaruh secara positif terhadap tingkat produksi, hal ini memiliki kesimpulan yang lebih masuk akal bahwa variabel jumlah buah kelapa sawit, jumlah tenaga kerja, jam kerja mesin, penggunaaan air, penggunaan uap dan suplay listrik akan berpengaruh positif terhadap tingkat produksi. Hal ini bisa terjadi karena dalam MCRR masalah multikolinieritas sudah tidak ada.

\section{KESIMPULAN}

Pada model data tingkat produksi Crude Palm Oil (CPO) terdapat masalah multikolinieritas pada variabel jumlah buah kelapa sawit, jumlah tenaga kerja, jam kerja mesin, dan penggunaan air. Sehingga untuk menangani maslaah multikolinieritas digunakan regresi MCRR. Dengan persamaan model dari regresi MCRR adalah sebagai berikut:

$\hat{Y}=-315.776+0.04341 X_{1}+0.49865 X_{2}+1.09091 X_{3}+0.03315 X_{4}+0.05342 X_{5}+0.00181 X_{6}$

Dari hasil analisis yang telah dilakukan regresi MCRR memiliki nilai koefisien determinasi yang cukup besar dan koefisien yang dihasilkan berepengaruh secara positif terhadap variabel tingkat produksi, sehingga kesimpulan yang diambil menggunakan MCRR lebih tepat dan masuk akal.

\section{DAFTAR PUSTAKA}

Achmad, A.I., (2008). Analisis Regresi. Program Studi Statistika Universitas Islam Bandung.

Batah, F., Ozkale, M. R., Gore, S.D., (2009) Combining Unbiased Ridge and Principal Component Regression Estimators. Journal of Communications in statististic- Theory and Methods Vol: 38, No. 13: 2201-2209.

Baye, M and Parker,D. (1984). Combinng Ridge and Principal Component Regression : a Money Demand Ilustration. Journal of Communications in statististic- Theory and Methods Vol: 13, No. 2: 2201-2209.

Crouse, r., Jin, C., Hanumara, R.C., (1995). Unbiased Ridge Estimation ith Prior Infoermation and Ridge Trace. Journal of Communications in statististic- Theory and Methods Vol: 24, No. 9: 2341-2354.

Hajarisman, N., (2011). Analisis Regresi Lanjut. Program Studi Statistika Universitas Islam Bandung.

Hoerl, A. E. dan R. W. Kennard., (1970). Ridge Regression: Aplikation s to Nonorthogonal Problems. Technometrics. Vol: $12: 55-56$.

Jhonson, R and Wichern, W. (2007). Applied Multivariate Statistical Analysis. New York: Prentice Hall, Inc.

Jollife, I.T. (2002). Principl Component Anaysis. Springer.

Kutner, M. H., Nachtsheim, C.J., Netter, J., and Li, W., (2005), Applied Linear Statistical Models, 5rd ed., McGRraw-Hill : Irwin.

Myers, R.H. (1990). Classical and Modern Regression with Applications. Boston, MA: Duxburry.

Netter, J. Wasserman, W. And Kutner, M.H. (1990). Applied Linier Statistical Models. Tokyo: Richard D. Irwin, Inc. 